\title{
The Viability of Vertical Restraints
}

Doctrine

\author{
William F. Baxter
}

The prevailing substantive antitrust rules governing vertical arrangements are anomalous in several respects. One anomaly may be that the rules reflect a political standoff likely to prove quite stable over time. If stability connotes viability, the rules of vertical restraints may be botli viable and anomalous.

The vertical rules lave had a chaotic, an anti-intellectual, and, in some senses, a belated development. Unlike the early cases involving horizontal restraints, none of the early vertical restraints cases wrestled with economic principle and explored the implications of the then-rudimentary learning about price theory or industrial organization. Some of the earliest cases were tie-in cases such as the Button-Fastener case ${ }^{1}$ and A.B. Dick. ${ }^{2}$ In those cases, a tie appears to have been used to meter demand elasticity, or perliaps for quality control. But the permissive and sensible lines of development that started liere did not survive the Motion Picture Patents case. ${ }^{3}$

Cases involving resale price control had roughly simultaneous beginnings, but their first appearance was not in the context of a promise by the downstream party to maintain price. Instead, the early cases involved attempts by owners of patents or copyrights to sell protected items and condition the license to resell on maintenance of the resale price. Early endeavors to use intellectual property licensing in that way failed, the Court said, because "in the essential nature of things, when ... the person having ... riglits [in a patent] sells ... he parts witl the right to restrict ... use. The article ... passes without the limit of the monopoly." 4 This explanation was more metaplyysical than analytic. Nonetlieless, it cast a long sliadow.

The issue of contractual limitations on resale price first reached the Supreme Court in the Dr. Miles case. ${ }^{5}$ Although the earlier intellectual

$\dagger$ William Benjamin Scott and Luna M. Scott Professor of Law, Stanford University. A.B. 1951, J.D. 1956, Stanford University. Assistant Attorney General of the United States, Antitrust Division, Department of Justice, 1981-83.

1. Heaton-Peninsular Button Fastener Co. v. Eureka Specialty Co., 77 F. 288 (6th Cir. 1896).

2. Henry v. A.B. Dick Co., 224 U.S. 1 (1912).

3. Motion Picture Patents Co. v. Universal Film Mfg. Co., 243 U.S. 502 (1917).

4. Adams v. Burke, 84 U.S. (17 Wall.) 453, 456 (1873).

5. Dr. Miles Medical Co. v. John D. Park \& Sons Co., 220 U.S. 373 (1911). 
property cases and their metaphysical assertions about the capacity of covenants to run with chattels were influential, Dr. Miles was one of the very few cases in which the Court attempted to examine the propriety of a vertical practice in terms of its effect on human activity. Unfortunately, Justice Hughes, writing for the majority, reached the understandable but demonstrably erroneous conclusion that price control imposed by a manufacturer on a set of dealers has the same consequences as a dealer cartel. In fact, the consequences are different because the desired price levels are different.

The misstep in Dr. Miles was quickly followed in Motion Picture Patents. $^{6}$ As in A.B. Dick, the license to use a patented machine was conditioned on the use of a complementary variable input supplied by the licensor. The Motion Picture Patents case, however, may have involved an attempt to use a soon-to-expire patent as a lever to achieve a more durable position of market power in film production; so its outcome was not necessarily wrong. But its metaphysical language, combined with its oblique reference to section 3 of the Clayton Act, ${ }^{7}$ gave rise to a distorted view of section 3 , a view that fails to limit that section to situations where imposing the prohibited condition substantially lessens competition.

Had these arid doctrines promptly given rise to all the commercial mischief they make possible, they might have been reexamined while they were still malleable. Fortunately for the commerce of the day-but unfortunately for doctrinal development-this did not occur. Demand elasticities can be metered by revolution counters as well as tie-in sales, and that remained a lawful basis for discriminating royalty charges, although a wastefully more costly basis. Furthermore, the resale pricemaintenance decisions were without any substantial operational effect. Occasionally, a legally ill-advised enterprise fell into the trap, but most of the business community bypassed Dr. Miles by employing the agency device. Indeed, the manufacturer in $D r$. Miles apparently intended to create agency relationships with the wholesalers and retailers who signed the distribution contracts, but was thwarted by bad lawyering. The Supreme Court, of course, upheld use of the agency device in the 1926 General Electric case. ${ }^{8}$ Once the Court put its blessings on the particular verbal formulation used in General Electric, scores of firms hastened to adopt the identical wording, modified only as was absolutely necessary to adapt the contract to the marketing of pharmaceuticals or toasters or laundry detergent rather than light bulbs.

The Fair Trade laws enacted during the 1930's afforded an alternative route around $D r$. Miles, though in some senses a less satisfactory one.

6. Motion Picture Patents Co. v. Film Mfg. Co., 243 U.S. 502 (1917).

7. 15 U.S.C. $\S \S 12-27$ (1982).

8. United States v. General Elec. Co., 272 U.S. 476 (1926). 
First, Fair Trade was limited to pricing. In contrast, the agency relationship created an ersatz form of complete vertical integration that would shelter other kinds of restrictions as well. Second, the lack of Fair Trade laws in some states precluded implemention of a nationwide marketing system based on Fair Trade. Finally, state-imposed limitations and procedural requirements made Fair Trade enforcement very expensive, and, with the passage of time, an ever-larger number of states adopted such restrictions. ${ }^{9}$

When at last the Court eliminated the agency device in Simpson $v$. Union Oil Co., ${ }^{10}$ one of the most dishonest opinions of all time in a field with many serious contenders, the loss in flexibility was real. Only Fair Trade was left. Nevertheless, by the time Congress eliminated the Fair Trade exemption, only a small number of marketers of complex consumer items, such as hi-fi equipment, appear to have been using the system. No one can know how many more enterprises would have availed themselves of resale price control agreements if there had been available a legally secure path without the extremely high enforcement costs and incomplete geographic coverage that characterized Fair Trade.

In this brief historical sketch, I have emphasized resale price control primarily and tie-in agreements secondarily because, historically, legal prohibition began with those devices and, with rare exceptions, now continues only with those devices. Other vertical arrangements suffered condemnation later and, for the most part, were rehabilitated sooner. Exclusive dealing was substantially prohibited by the Standard Stations case $^{11}$ in 1949 and for the most part was rehabilitated in Tampa Electric $^{12}$ in 1961. Territorial and customer limitations were acquitted by a scotch verdict in White Motor ${ }^{13}$ in 1963, were held illegal per se in Schwinn ${ }^{14}$ in 1967, and were rehabilitated by GTE Sylvania ${ }^{15}$ in 1977. One cannot reasonably ascribe coherence to all these doctrinal convolutions. It is almost as difficult to suppose that any commentator could find the present state of the law satisfactory. Surely neither resale price control nor tie-ins are so bad, nor other forms of vertical restriction so benign, as to justify the sharp categorical differences in their present legal status.

In substantial part, the overly rigid dichotomy is attributable to the dichotomy between per se violations and the rule of reason, itself one of

9. See Fulda, Resale Price Maintenance, 21 U. CHI. L. Rev. 175 (1954) (reviewing early history of Fair Trade statutes and difficulties associated with their enforcement).

10. 377 U.S. 13 (1964).

11. Standard Oil Co. v. United States, 337 U.S. 293 (1949).

12. Tampa Elec. Co. v. Nashville Coal Co., 365 U.S. 320 (1961).

13. White Motor Co. v. United States, 372 U.S. 253 (1963).

14. United States v. Arnold, Schwinn \& Co., 388 U.S. 365 (1967).

15. Continental T.V., Inc. v. GTE Sylvania, Inc., 433 U.S. 36 (1977). 
the most deplorable features of the antitrust landscape. However frequently the courts intone that "[i]t is only after considerable experience with certain business relationships that courts classify them as per se violations," 16 the fact remains that the statement is false. The courts have repeatedly invoked the per se label without the faintest comprehension of the commercial functionality of the practices they were condemning. One need only go back as far as the Maricopa County case, ${ }^{17}$ which brought before the Supreme Court new practices in the field of medical insurance coverage, practices quite different from any within the Court's experience. As this case demonstrates, if per se condemnation is made before understanding is achieved, understanding may never be achieved; the legal classification precludes the development of a trial record that would elucidate the challenged practice.

On the other hand, those practices subject only to the rule of reason will rarely, if ever, be found illegal if a plaintiff or enforcement agency must carry the burden of showing that human welfare is reduced by this particular use of the particular restriction in this particular set of markets at this particular time. Coherent antitrust doctrine will develop only if we move to systems of characterization less global than we have used in conjunction with per se rules, and at the same time abandon a rule of reason concept that regards the process of characterization as wholly unnecessary.

Characterization appropriate for sensible resolution of vertical arrangement cases would begin by identifying the conditions under which such arrangements might possibly cause economic harm. Treating antitrust law as a form of purposeful activity intended to improve the lot of human beings in some fairly general sense, what harms can we reasonably fear might flow from the use of restrictive vertical arrangements? So far as I am aware, not even the most committed defender of doctrinal status quo or status quo ante has made a coherent argument that vertical arrangements, in and of themselves, cause social harm apart from the exercise of market power at either of the two adjacent levels of commercial activity joined by the arrangement. Rather, the argument always is that the vertical arrangement is being used either to facilitate the creation of market power at one level or the other or to exploit an existing position of market power.

Positions of market power can usefully be subdivided into two categories, each having two subcategories: (1) market power, coveted or possessed, by a dominant firm; and (2) market power, coveted or possessed, by a colluding group. I will inquire how occupants of each of those four cells might employ some vertical arrangement to achieve their goals.

16. United States v. Topco Assocs., 405 U.S. 596, 607-08 (1972).

17. Arizona v. Maricopa County Medical Soc'y, 457 U.S. 332 (1982). 
Obviously the mere existence of a position of market power does not adequately explain why a vertical restraint is employed. In the great preponderance of circumstances, market power would be exercised or pursued directly in the primary market in which the firm or group buys or sells. We must consider, then, under what circumstances it is reasonable for a firm or group possessing or seeking market power to prefer restrictive vertical arrangements between itself and firms at an adjacent level of commercial activity.

In examining this question, it is helpful to keep foremost in mind a relationship frequently ignored in discussions of vertical arrangements: Attainment or exploitation of market power by a firm or group will harm, and hence will be resisted by, all other firms engaged in complementary activity. It is customary in discussions about industrial organization to focus on the physical movement of products-from the ore pit to the basic metal producer to the fabricator, and, through distribution channels, to the final consumer. Often, the physical product's direction on this journey is called "downstream;" the enterprises from which the product moves are "upstream." "Forward" and "backward" vertical integration are terms used in similar senses. Moreover, it is a familiar concept that if an enterprise exerts substantial market power in the web comprised of all enterprises, firms (or consumers) "downstream" from it will be hurt, for they will be required to buy their inputs (consumption goods) at monopoly prices. This elevates their costs and impairs their ability to compete (satisfy their consumption need) with those direct or indirect competitors that, for one reason or another, need not buy inputs in the monopolized sector.

In short, traditional modes of discourse imply that there is directionality to the harms done by the successful imposition of monopoly rents. There is no such directionality. The losses and distortions caused by the exercise of market power are just as likely to flow upstream as down. The terms upstream and downstream are merely figures of speech. It is totally arbitrary to regard a retailer as being downstream from a wholesaler. It is equally accurate to think of the wholesaler as dealing directly with final consumers and purchasing retail distribution services as one of the wholesaler's inputs as it is to think of the retailer as buying product inputs from the wholesaler for further distribution to consumers.

Rather, the harms and distortions that are generated by the exercise of market power flow in all directions and affect all firms that deal, directly or indirectly, with the enterprise that exercises market power. The extent to which any neighboring firm will be hurt by distortions in the form of reduced output will depend entirely on the elasticity of the supply and demand curves that lie between the affected firm and the firm 
with market power. However, both upstream and downstream firms contracting directly with the firm possessing market power are the most likely to be hurt and to be hurt most substantially. Thus, if wholesalers hold and exercise market power, the manufacturers from whom they buy and the retailers to whom they sell are the most probable victims and are probably victims in equal degree.

Consequently, scenarios that involve a firm or firms at one level of activity using vertical restraints deliberately to confer market power on firms at an adjacent level are inherently suspect. To do so is, typically, to inflict self-injury, just as it would be for consumers to confer market power on the retailers from whom they buy.

With that admonition in mind, I turn to the four cells of a $2 \times 2$ matrix. There are dominant firms and groups along one axis. Along the other, there are subtypes of market power, possessed and only coveted.

A dominant firm exercising presently held market power is the simplest case. By definition, the firm is in a position to cause harm to its customers and to its suppliers. It may do so by setting a single price uniformly above its marginal costs, or it may engage in some form of price discrimination. It is technically correct to say that we cannot know for sure whether the harm caused by the exercise of market power will be greater or less if exercised through uniform monopoly markups rather than through price discrimination. For a variety of probabilistic reasons, price discrimination is more likely to cause output to increase than to decrease; increases in output will probably reduce both upstream and downstream distortions. However, in each case the welfare effects are ambiguous, not because the output effects are ambiguous, but because the administrative costs of the discriminating scheme may exceed the gains that will result from increasing output.

I make these general points about price discrimination preliminary to observing that a dominant firm possessing market power might use any of the various well-known vertical arrangements to implement discriminatory exploitation. Tie-in sales of the metering type are the most obvious. Alternatively, if a network of downstream dealers is appropriate to the circumstances, imposing either territorial restrictions, customer restrictions, or both, on the dealers may make it possible for the downstream dealers to engage in price discrimination, each within an assigned market, on behalf of the dominant firm. Because the dominant firm can assign quotas, use multipart pricing schemes, or even threaten its dealers with replacement, it can protect itself from the harm that would otherwise flow from bestowing market power on its own dealers. But, again, there is no reason to think that the social consequences are less favorable than those that would flow from uniform monopoly pricing. 
Those who favor prohibition of price discrimination suggest that denial would discourage firms from seeking out positions of market power. In my view, this assumes an unjustified normative attitude toward positions of market power in all its manifestations. Positions of market power come in all sizes and shapes and from many histories. In particular, they are strongly correlated with innovation, which may mean inventing the metal oxide semiconductor or building the first saloon in a small town. I do not believe that categorical reduction of rewards to positions of market power, without reference to their character or method of attainment, can be justified.

Without justification for a categorical denial of returns to market power, why should we incur the social expense of enforcing prohibitions against the use of vertical arrangements that implement discrimination? If the character and origin of the dominant firm is such that we wish to discourage others from imitating its behavior, then section 2 of the Sherman $\mathrm{Act}^{18}$ should be employed: Confining the firm to uniform monopoly markups is far short of sufficient. If, for whatever reason, we are unable or unwilling to eliminate the dominance of the firm, attacking its implementation of price discrimination through use of vertical arrangements is pointless. It is not merely pointless but bizarre to attack price discrimination when the firm uses tying but not when it employs revolution counters or the endless variety of alternative devices.

Nonetheless, if price discrimination by dominant firms is deemed aesthetically objectionable, it is easy to identify the necessary conditions for its operation. There must be a primary market in which there is a firm with a very large market share, and entry into that market must be difficult. In the case of tie-in restrictions, there must in fact be a tie to a second product supplied by the dominant firm or its nominee, and that product must be used in varying proportions by different customers. In the case of the territorial or customer restrictions, there must be, in addition to primary market dominance and entry barriers, relatively easy entry into the adjacent market, at least with the cooperation of the dominant firm. Without this the dominant firm would be unable to protect itself from injury caused by the position of market power it has created in the adjacent market.

Of course, even when these necessary conditions are met it may be ambiguous whether the practice is serving still other, perhaps highly efficient, functions. For example, a tie-in arrangement, or an arrangement indistinguishable from a tie, can be used by an innovator to share with its customers the risk of introducing an expensive new piece of capital equipment, as appears to have been the situation in the old IBM punch

18. 15 U.S.C. $\$ 2$ (1982). 
card case. ${ }^{19}$ Alternatively, in some circumstances the tie may be the most efficient method for assuring the quality of the variable input and thus for assuring performance of the tying capital item. Such quality concerns may have motivated the tie-in arrangements in A.B. Dick ${ }^{20}$ and Chicken Delight. ${ }^{21}$ In short, satisfaction of the necessary conditions for abuse will rarely amount to satisfaction of the sufficient conditions. One must consider, then, whether the high litigation costs of allowing proof of business justification counsel abandonment of the prohibition within the category in question. In the case of dominant firm exploitation of existing market power, my own view is that the game, quite plainly, is not worth the candle. ${ }^{22}$

Situations in which dominant firms seek to establish new positions of market power rather than to exploit existing positions are more interesting. They come in two varieties. First, a firm dominant in one market may seek to establish a position of market power in a different but related market. For this purpose, exclusive dealing arrangements or tie-in arrangements may be useful. This type of "foreclosure" is the favorite explanation courts offer for all tie-in arrangements and many exclusive dealing arrangements, even though the necessary conditions are seldom satisfied. If a dominant position is to be established in the market for a tied product by means of a tying sale, the firm employing the tactic must, first, have a dominant position in the primary market for the tying product. If not, customers for the tied product will be free to purchase either product from other sources. Second, customers who use the tying product must constitute the preponderant source of demand for the tied product. If this is not the case, even though the dominant firm may achieve a certain patronage for the amount of the tied product that is used with the tying product, there will be ample room for other producers of the tied product to participate in the market. Finally, entry into the markets for both the tying and tied products must be difficult. If the tying market is easily entered, the dominant firm does not have any market power with respect to the tying product. Likewise, if the tied market is easily entered, it is pointless to achieve a position as the major supplier of the tied product, for supra-competitive prices cannot be maintained in the face of entry.

Under certain conditions, a firm dominant in a primary market and bent on dynamic abuse, as opposed to static exploitation of existing market power, will find exclusive dealing arrangements useful. The firm may

19. International Business Machines Corp. v. United States, 298 U.S. 131 (1936).

20. Henry v. A.B. Dick Co., 224 U.S. 1 (1912).

21. Siegal v. Chicken Delight, Inc., 448 F.2d 43 (9th Cir. 1971).

22. Similar admonitions regarding the difference between necessary and sufficient conditions, and the social costs of adjudication, pertain to the various arguments that follow. 
try to achieve a new position of market power in an adjacent market or to protect the primary position of market power from entry and erosion. The first two necessary conditions are a dominant position in the primary market and difficulty of entry into the primary market. Without these conditions there would be nothing worth protecting in the primary market and no fulcrum for foreclosure in the adjacent market. Given these conditions, the dominant firm may predatorily preempt by purchasing "more than it needs" of some input or facility that is important to its smaller competitors or potential competitors, causing marginal cost of the input to rise for all firms. Finally, a successful primary market protection scheme also requires that there be serious barriers to entry into the adjacent market where the preemptive purchasing occurs. If entry is easy, the competitors or potential competitors in the primary market who are to be squeezed will enter the adjacent market or stimulate entry there by others. If an independent position of dominance is sought in the adjacent market-a less likely possibility since adjacent market dominance is of relatively less value to a firm with primary market dominance-entry difficulties are necessary for the position to be of any value.

Preemptive buying schemes have much in common with predatory pricing and face many of the same difficulties. The dommant firm must invest today in overpurchasing in the secondary market so that it can earn monopoly rents in the future for an uncertain period of time. Still, one can imagine circumstances in which an exclusive dealing squeeze-out case presents fewer difficulties than a predatory pricing case. The impact on rivals' costs is immediate, the time horizon over which the investment must be made may be shorter, and the cost to the dominant firm will not necessarily be as disproportionately large as is the size of the dominant firm in comparison with the size of victims of the scheme. ${ }^{23}$

As one moves from the cells involving dominant firms to the cells involving present and coveted market power based on collusion, identification of necessary conditions becomes more complicated. In both these cells, the conditions for effective collusion are obviously a threshold requirement. There must be a high degree of concentration in the primary market, entry to that market must be difficult, and the characteristics of the product or service must not be so highly individualized that the unit to which the agreed price or output restriction applies cannot practicably be defined. If the suspected group bears these characteristics, one must ask why they seek to attain their ends by use of vertical

23. Preemptive purchasing is perhaps the most appealing of Professor Salop's examples of "raising rivals' costs," See, e.g., Salop \& Scheffman, Raising Rivals' Costs, 73 Am. Econ. Rev. 267 (1983); Krattenmaker \& Salop, Anticompetitive Exclusion: Raising Rivals' Costs to Achieve Power Over Price, 96 YALE L.J. 209 (1986). 
arrangements rather than by simply confronting their customer set with familiar cartel arrangements.

Out of the traditional list of vertical restraints, only two conceivably might be of assistance in collusive exploitation of presently held market power: resale price maintenance (RPM) and customer restrictions. I consider RPM first. A concentrated group of sellers in the primary market might find themselves unable to collude successfully with respect to their own selling prices because of cheating within the group. The cheating might take any number of forms: delivery of off-invoiced free goods, freight absorption, allowance of discounts for prompt payment when payment was in fact delayed, and so forth. Any of these tactics could cause customers in the adjacent market to desire greater quantities of the cheater's output and lesser quantities from those who were abiding by the rules. If the firms in the adjacent market resell the product produced in the primary market in a form that allows easy identification of its primary market source, as would be true of almost any branded good, and if the firms in the adjacent market cannot significantly influence the extent to which their customers call for one brand or another other than by price discounting, then it may be easier for the firms in the primary market to enforce their cartel arrangement by policing resale prices in the adjacent market than by attempting to police selling prices in the primary market.

For RPM to facilitate cartel arrangements, the first necessary condition is a highly concentrated primary market in which the proportion of upstream sellers using RPM is sufficiently large to make it possible for the subgroup to function successfully as a cartel. ${ }^{24}$ Clearly, unless concentration levels are extraordinarily high, substantially all firms must use the restraint or this "plausible cartel" condition will not be met. Second, there must also be significant barriers to entry at the primary market level. A third necessary condition is that a substantial preponderance of the product sold in the adjacent market be subject to the restraint. Although this condition is usually satisfied if the first condition is, it provides for the admittedly unusual situations that involve substantial asymmetries in the use of the vertical restriction in the primary as opposed to the adjacent market. ${ }^{25}$

24. In making this assessment it is appropriate to treat any firm that is vertically integrated across the primary and adjacent market as a firm that uses the restraint. In short, here and in other collusion cells, vertically integrated firms are presumed to be using any and all vertical restraints that come into question.

25. Usually, if the firms at the upstream level employing the restraint supply some proportion - for example, $60 \%$ of the output at that level - then a like proportion, $60 \%$, of the product resold in the adjacent market will be sold subject to the restraint. But occasionally this will not be so. Suppose, for example, that four $15 \%$ firms manufacture and sell $60 \%$ of widgets produeed in the United States and the remaining $40 \%$ is produced by a fringe of eight $5 \%$ firms. Assume, however, 
Of course, the colluding group need not be the upstream group. Those who prefer to view RPM with alarm seem convinced that the vertical arrangement is more often imposed by colluding downstream retailers upon upstream manufacturers. That may indeed be so in some cases, and I will address that particular possibility below.

I can imagine only one other circumstance in which existing, collusion-based market power might be facilitated by a vertical arrangement. This involves customer restrictions in which a concentrated group of primary market suppliers reach a major fraction of final users through a set of downstream dealers. Sales to dealers may occur at prices at or near marginal costs because of the impracticality of monitoring cartel pricing to the dealers or, alternatively, because most final users to whom the dealers sell have good substitutes so that their demand from dealers is highly elastic. Assume further, however, that there is also a substantial subset of final users to whom the primary market firms may feasibly sell directly, and that collusion with respect to them is feasible. To make a cartel effective, it is necessary to prevent the dealer network from competing for the patronage of those buyers to whom direct selling is practicable. That objective can be accomplished if all primary sellers adopt customer restrictions that prevent the dealers from performing the arbitrage function. Once again, the necessary conditions are a very high level of concentration in the primary market, widespread use of the customer limitation by firms in the primary market, significant entry difficulties to the primary market, and systematically higher price levels to the endusers served directly than to the restricted distributor network.

Credulity is badly stretched, probably beyond the breaking point, as one tries to fashion a plausible story in which a group of firms might employ a vertical restriction to achieve market foreclosure. Exclusive dealing arrangements seem to be the only remotely tenable possibility. A concentrated group of sellers in the primary market might attempt to fend off entry, or to squeeze out an existing competitive fringe, by predatorily purchasing "more than they need," and thus driving up the price in the adjacent market. Here as elsewhere, upstream or downstream is a matter of indifference. In an upstream adjacent market, the practice might take the form of a pattern of exclusive dealing arrangements with the providers of a natural resource; in a downstream market, it might take the form of exclusive dealing arrangements with distribution entities. The Standard Stations facts ${ }^{26}$ satisfy some but not all of the neces-

that the four $15 \%$ firms are each significant sellers in foreign countries, with half the output of each sold there. In this case, the "big four" are the source of only 30 units of widgets out of a total of 70 units that are resold in the U.S. markets. Because almost $60 \%$ of domestic distribution is not subject to the vertical restraint, it is impossible for RPM to serve as a cartelization device.

26. See Standard Oil Co. v. United States, 337 U.S. 293, 295-97 (1949). 
sary conditions. Notice that it is not sufficient for the firms in the primary market merely to purchase their needs in the adjacent market, for that would leave available to competitors in the primary market a supply of inputs to the adjacent market proportionate to their needs. Preemptive purchase of capacity in adjacent markets, if not excessive purchase of the input itself, are necessary to have a significant foreclosure effect.

The necessary conditions for exclusive dealing to facilitate cartelization are a high level of concentration' in the primary market, difficulties of entry into the primary market, widespread use of the exclusive dealing arrangement by all or substantially all of the major firms in the primary market, and substantial difficulties of entry into the adjacent market so that the victimized primary market competitors do not find it feasible themselves to enter, or stimulate entry into the adjacent market, individually or through a joint venture. Finally, the colluding firms must be able to monitor and ascertain that each is carrying a fair share of the burden of predatory purchasing. Since, by assumption, each firm will buy the input in substantial quantity whether or not it is doing its fair share of preemptive buying, monitoring will be very difficult in most circumstances.

One other fact situation merits discussion because supporters of the per se rule against resale price agreements think it represents a problem. The basic notion is that upscale retailers in each or most retail market areas coerce the manufacturers of well-known brands to engage in resale price maintenance in order to eliminate price competition with respect to those brands among the upscale retailers and between the retailers and discounters. The demand that the manufacturers employ RPM is enforced by threats, at least in form unilateral, to refuse to carry the brand unless it is subjected to price maintenance. Such competition as might otherwise exist between upscale and downscale establishments is attenuated because the downscale merchants will not carry a brand unless they can discount it, in part because discounting is the major theme of their marketing and advertising, and in part because, comparing unfavorably with upscale establishments in terms of service and physical amenities, downscale merchants cannot compete on identical merchandise at equal prices. Thus, the upscale merchants are able to earn monopoly rents.

While superficially plausible, this scenario is dubious for several reasons. First, except in small, isolated communities, retail markets rarely exhibit the levels of concentration necessary for the exercise of cartel behavior. The most obvious form of cheating, acceptance of merchandise other than pursuant to price-maintained arrangements and sale at prices below those set by other upscale merchants, is very easily 
observed. But other forms of competition are just as devastating to retailer margins; namely, competition in display and other forms of promotion, and in provision of services and physical amenities.

Second, collection of monopoly rents by retailers would be very damaging to the adjacent market sellers, the owners of the brands. They should be expected to resist vigorously and to attempt to subvert the retailers' efforts. Historically, where resale price maintenance was used there was no indication that manufacturers used it only, or even primarily, as a result of retailer coercion. If not its chief proponents, manufacturers were usually more than willing accomplices.

Third, the story implicitly assumes that upscale retailers and downscale retailers compete to the extent that they carry the same brands but do not compete to the extent they carry different brands. It would be amazimg if that particular relationship held up across geographic markets with very different characteristics. A relationship more likely to hold across markets is the following: For some low-income and some highincome groups, the two types of outlets are imperfect substitutes, but for a substantial block of the population they are effective substitutes whether or not the same brands are carried. Although I know of no empirical data that would quantify the proportion of all consumers in this middle group, I would be amazed if the group were not large enough to induce very high elasticities in the effective demand curves confronting both groups of merchants.

Those who think this scenario is realistic frequently cite as evidentiary support a datum that does not, in fact, lend support. They assume that if it can be shown that resale price maintenance causes consumer prices to be higher, then one has successfully shown that pricing is not competitive and that consumers have been harmed. That is quite wrong. There is no dispute over the proposition that the purpose and probable effect of resale price maintenance is to maintain retail margins at higher levels than would prevail in its absence, at least in the short run. Higher margins may not yield higher prices. First, the manufacturer's optimizing wholesale price will often be lower if he can adopt RPM over his entire geographic market. Second, the manufacturer's costs are likely to be lowered because RPM induces retailer activities-promotion, for example-that enable the manufacturer to cease his own more costly activities of the same type. But for present purpose I assume higher prices do result.

Higher retail prices are entirely consistent with the benign explanation of resale price maintenance. Imposition of RPM reflects a judgment on the part of the brand owner that her products will compete more successfully, both against other branded products and against generic rivals, if the retailer competes along parameters other than price. And 
the retailer's expenses of engaging in those other forms of rivalry are financed by setting a retail margin higher than would prevail if retail price competition were allowed or encouraged.

The higher retail price, itself, unquestionably tends to reduce the volume of product sold. Because the demand curve confronting the individual brand owner is of more than unitary elasticity, the higher price will tend to reduce revenue. Accordingly, the practice will damage the manufacturer unless the induced nonprice rivalry achieves increases in sales volumes that more than offset the volume-depressing effect of the price increase. Of course, any given manufacturer may be mistaken in his belief that these other modes of rivalry can shift the demand curve for his product up and to the right in an amount sufficient to more than compensate for any price enhancement, but it is impossible to believe that manufacturers in general systematically err in that assessment.

Consumers may benefit, despite higher short-run prices, for a mix of reasons. First, in both the short and long runs, the physical product is made more valuable to consumers by the associated information or services. The services often take forms, such as informational advertising, that reduce consumers' shopping costs and hence the delivered cost of the product. Although these conditions will not hold for all consumers, they must hold for a sufficiently large number to shift the demand curve as described above. If not, the RPM is contrary to the interest of both supplier and retailer.

Secondly, consumers also benefit in the long run. A community that permits resale price maintenance increases the relative profitability, and hence the availability, of products that are dependent upon providing a rich set of service complements such as point of sale instruction, postsale warranty services, local advertising, and other free-rider susceptible service complements.

However the ultimate issue of net benefits may work out for any particular product, it seems clear that the necessary conditions for cartel facilitation are essentially the same in downstream, dealer cartel cases, as in the upstream case previously discussed: the retail market must be highly concentrated, substantially all retailers selling the product must be subject to the restriction, substantially all upstream suppliers of the product must insist upon the restriction, and entry must be difficult at the retail level. These conditions will be satisfied, I believe, far less often than advocates of this theory seem to believe. Not only are the number of retail outlets in most markets too numerous to meet the primary market concentration condition, but the entry condition, properly understood, will usually fail. Typically, entry will be relatively easy, not because new establishments will be built to become specialty dealers in the affected product, but rather because existing establishments that have 
not heretofore carried the product will find it profitable to add it to their product line. And the upstream suppliers, already chafing from the injury done by exploitation of market power in the adjacent market, will have strong incentives to cooperate with such new outlets.

If I am in error about the frequency with which the conditions will be satisfied, so be it. Surely the necessary conditions-to say nothing of sufficient conditions-will fail with respect to some products and some retail markets far too often to allow justification of today's categorical per se rule.

The foregoing discussion illustrates that we now know enough about industrial organization, cartel theory, and dominant firm behavior to identify those conditions that must be satisfied before one may reasonably conclude that use of a particular vertical arrangement in a particular context is likely to cause social harm. I turn now from identification of necessary conditions to the question of how one might weave those conditions into a fabric of sensible rules.

Ideally, one would review the various vertical restrictions surveyed in this paper, examine the contexts in which they are employed, and ascertain the extent to which they achieve savings of transaction costs, reductions in risk, alignments of incentives that reduce the frequency of opportunistic behavior, or perform still other socially useful roles. One would then balance, in each commercial context, the potential harms and benefits of each type of vertical arrangement. Unfortunately, we do not know nearly enough about the precise roles these arrangements play, and certainly not enough about the magnitude of the benefits they yield, to engage in that ideal analysis. We do know, however, that the arrangements are beneficial, and at worst benign, in the great preponderance of cases. Casual inspection of the contexts in which vertical arrangements are employed reveals that the necessary conditions for their being harmful are rarely satisfied. This is apparent even if one merely inspects those arrangements that have been subjected to legal challenge and that are therefore described in existing case law.

My central proposition, that all vertical arrangements should generally be presumed benign, rests on two pervasive relationships. First, insufficient account has been taken, historically, of a point already sufficiently developed in this paper: If a particular arrangement is being employed to facilitate the exercise or attainment of market power, one or more entities whose cooperation is essential is very likely to be injured by the practice and can be expected to resist.

Second, it is becoming ever more clear from contemporaneous work on the theory of the firm, ${ }_{2}^{27}$ particularly when that work is viewed in the

27. See O. Williamson, The Economic Institutions of CApitalism (1985). 
context of general equilibrium theory, ${ }^{28}$ that the contours of the business firm are dictated largely by the need to overcome market imperfections. Given the usual assumptions about a perfectly competitive world in which all information is known, all resources are infinitely divisible, and so forth, equilibrium theory has shown, without resort to the concept of firms, that all markets clear with optimal results. Firms are motivated, as Williamson so persuasively argues, by the need to overcome market imperfections. Contracts that deal with all future contingencies cannot practicably be written; in the absence of such contracts individuals do behave opportunistically; gains from investments in developing information are difficult to appropriate; and the transaction costs of dealing entirely through spot markets are often prohibitively high.

But the business firm cannot be regarded as a well-defined, polished sphere within which certain resources have been wholly internalized so as to cope with market imperfections; that is, an entity that, having set its own boundaries, deals with all other entities and all other resources via spot markets. Rather, vertical arrangements of the kind discussed here should be seen in the context of the theory of the firm and as extensions of the firm. Vertical arrangements are instances of incomplete resource internalization, of partial vertical integration-instances in which the underlying market failure the arrangements address can be dealt with more effectively through the looser relationship of contract, and without incurring the bureaucratic costs inherent in tighter integration through ownership and employment.

If we conclude that the prototypical use of the vertical arrangement is as a form of partial vertical integration, then it immediately follows that use of antitrust rules that interfere with their employment should be limited to the minimum necessary to protect against the evils associated with market power. Thus, although one could produce a body of rules merely by regarding as sufficient the conditions that are prerequisite to any anticompetitive injury, that course is ill-advised if a manageable alternative exists. I believe there are manageable alternatives-indeed, I believe there are a substantial number of manageable alternatives-all of which are superior to existing antitrust doctrine. I will propose one. ${ }^{29}$

In my view, an enforcement agency or private plaintiff attacking use of a vertical arrangement must articulate some hypothesis about how the vertical restraint is being abused in a way that facilitates the exercise or formation of market power, and must then carry the burden of proving

28. See, e.g., K. ARrow, Social Choice and Individual V alues (Cowles Commission for Research in Economics Monograph No. 12, 1951); G. DEBreU, THEORY of VAluE: AN Axiomatic ANAlysis of ECONOMIC EQUilibrium (1959).

29. For an excellent discussion of antitrust rules based on whether or not conduct satisfies necessary conditions to do harm, see Easterbrook, The Limits of Antitrust, 63 TEX. L. REV. 1 (1984). 
that the necessary conditions associated with that hypothesis are satisfied. The burden of going forward then shifts to the defendant, who must establish that the vertical arrangement employed has characteristics that make it a suitable response to cope with some identifiable problem of market failure. For example, he may show that it reduces transaction costs, that it solves a free-rider problem otherwise present, or that it reduces risk and thus facilitates investment in specialized assets that would not otherwise be practicable.

If the defendant is able to carry that burden, he prevails unless the challenger, in turn, carries the burden of showing that the vertical arrangement was not in fact adopted in good faith in order to cope with the identified instance of market failure or, alternatively, that the adoption of the vertical arrangement was not unilateral but was a result of collaboration among competitors.

Needless to say, this proposal bears no close relationship to current case law. The proposal would treat resale price maintenance and tying substantially more permissively than does current case law. Conversely, it would treat all other vertical arrangements rather more restrictively, at least in the sense that it would afford a coherent theory as to what facts might render those other restrictions invalid. As a practical matter, current case law treats all other vertical restrictions as lawful per se.

I expect no groundswell of support for this or any similarly coherent proposal. Current case law is obviously very different, not only in its content but in its style of analysis. A majority of the Supreme Court appears determined to preserve the verbal formulations of longstanding per se rules even as it guts them of content, as it did, for example, in Jefferson v. Hyde ${ }^{30}$ and Northwest Stationers. ${ }^{31}$ Those cases yielded per se rules that are more accurately characterized as epithets to be used at the end of an opinion than as methods of analysis used near the beginning.

The prospects of congressional action appear to me at least equally bleak. Notwithstanding that the antitrust statutes Congress has enacted are extraordinarily vague and general and must be regarded as broad delegations of power to the courts to fashion sensible competition law, many members of Congress seem greatly troubled that courts exercise this delegation and go about the business of making and unmaking competition law without seeking Congress's permission in each instance. With Congress immobilized, the attorneys general of the several states have behaved, in all too many instances, as political opportunists, rushing in to supply incoherent and damaging state law doctrines, complete

30. Jefferson Parish Hosp. Dist. No. 2 v. Hyde, 466 U.S. 2 (1984).

31. Northwest Wholesale Stationers, Inc. v. Pacific Stationery \& Printing Co., 472 U.S. 284 (1985). 
with the associated populist rhetoric, where the federal law has been rationalized.

If viable means stable, then the present law of vertical restraints must be regarded as viable. Until the positions of the players become more fluid, and perhaps until it is possible to make much more specific and demonstrable quantifications of the benefits of vertical restrictions, it is difficult to see much prospect for change. 